\title{
Extractability and bioavailability of phosphorus in soils amended with poultry manure co-composted with crop wastes
}

\author{
Asma Saleem ${ }^{1}$, Muhammad Irshad ${ }^{1 *}$, Amjad Hassan ${ }^{1}$, Qaisar Mahmood ${ }^{1}$ and A. Egrinya \\ Eneji ${ }^{2}$ \\ ${ }^{1}$ Department of Environmental Sciences, COMSATS Institute of Information Technology Abbottabad Pakistan. \\ ${ }^{2}$ Department of Soil Science, University of Calabar, Nigeria.Corresponding author:mirshad@ciit.net.pk
}

\begin{abstract}
Intensive livestock production and poor agricultural management have resulted to excessive loading of soil with phosphorus (P), thereby contributing to environmental pollution and impairment of water quality. A study was carried out to determine the extractability and bioavailability of P in soils treated with poultry litter (PL) co-composted with sugarcane and cabbage wastes. The manure was applied based on total P contents at 200 and $400 \mathrm{~kg} \mathrm{P} \mathrm{ha}^{-1}$, with maize (Zea mays L.) as the test crop. The co-composted PL increased maize growth relative to PL alone with the best growth occurring at the treatment rate of $400 \mathrm{~kg} \mathrm{P} \mathrm{ha}^{-1}$. Maize biomass and available $\mathrm{P}$ in soil varied in the order PL co-composted with sugarcane waste and cabbage waste (\%) $50>33>25>0$. Phosphorus contents in maize shoot were higher in sandy clay than silt loam soil and its recovery was higher in soil treated with PL co-composted sugarcane waste than co-composted with cabbage waste. An amendment with co-composted $\mathrm{PL}$ increased the extractable $\mathrm{P}$ fractions and $\mathrm{P}$ availability in the soils. The $\mathrm{P}$ fractions in the postharvest soils varied in the order $\mathrm{HCl}-\mathrm{P}>\mathrm{H}_{2} \mathrm{O}-\mathrm{P}>\mathrm{NaHCO}_{3}-\mathrm{P}>\mathrm{NaOH}-\mathrm{P}$ and the fractions were significantly higher in the sandy clay than the silt loam soil. Also, the PL co-composted with sugarcane waste exhibited higher levels of $\mathrm{P}$ fractions in soils than co-composted with cabbage waste. Thus, co-composting poultry manure with crop wastes would better improve plant growth and $\mathrm{P}$ nutrition than sole-composted manure.
\end{abstract}

Keywords: Agro-waste, co-composting, poultry litter, phosphorus fractions, maize growth 


\section{Introduction}

Phosphorus (P) is an essential nutrient for plant growth and a plays vital role in energy storage, root development and early maturity of crops. Phosphorus is usually recycled to soil in the form of litter, plant residues and animal manures. Continuous fertilizer use increased soil P (Zhang et al., 1995), leading to environmental concerns. Even though $\mathrm{P}$ is not easily leached from the soil, it can be lost through soil erosion and runoff water. High concentrations of $\mathrm{P}$ in lakes cause eutrophication. Organic manures contain $\mathrm{P}$ and other essential plant nutrients, thus for crop production can get benefit from land application of manures through increased P fertility (He et al., 2006). However, excessive application of manure $\mathrm{P}$, especially poultry litter can in the long term increase the $\mathrm{P}$ transfer to soil and/or surface water. Thus, the use of poultry litter in agricultural lands with elevated $\mathrm{P}$ levels needs special management. When $\mathrm{P}$ fertilizers are applied to the soils, they are dissociated into the ionic forms and concentrations of ions in the soil solution are increased. In neutral soils, applied $\mathrm{P}$ fertilizer forms $\mathrm{Ca}$ and $\mathrm{Mg}$ phosphate minerals and a part is adsorbed on the surface of clay particles. This adsorbed $\mathrm{P}$ readily supplies $\mathrm{P}$ to the soil solution for plant uptake which is also referred to as labile P (Johnston, 2001). Phosphorus must be in the soluble orthophosphate form $\left(\mathrm{HPO}_{4}, \mathrm{H}_{2} \mathrm{PO}_{4}\right)$ to be taken up by the maize and all other plants (Snyder, 2002). The inorganic phosphorus ( $\mathrm{Pi}$ ) accounts for 50 to $90 \%$ and organic $\mathrm{P}$ represents less than $30 \%$ of the total P content (Romanya and Rovira, 2009). Poultry litter is a good source of P. Most of the P in poultry litter is inorganic (88-90\%) (Sharpley and Moyer, 2000). The development of better management practices to optimize the recycling of manure $\mathrm{P}$ and minimize the adverse environmental effects of animal manure is of public interest. The environmental problems associated with the application of raw poultry manure and fresh agricultural residues could be mitigated by stabilizing its nutrient and organic matter contents by composting before application to soils.

In most studies of agricultural soils, inorganic and organic $\mathrm{P}$ fractions are grouped into available, non-available, and recalcitrant pools (Fan et al., 2010). Composting is a process in which organic wastes of different origins are transformed into relatively stable materials (Fialho et al., 2010). Composting results in volume reduction, inactivation of pathogens and immobilization of nutrients, and produces humus-rich substances that are odorless (Mehta et al., 2014). When applied to soils, compost acts as a conditioner and remediation by improving the soil organic matter and moisture contents (Paradelo and Barral, 2012). Total $\mathrm{P}$ concentration in compost is important as it gives an idea of how much $\mathrm{P}$ is added into the soil when composts are applied to the soils. Fractionation of compost $\mathrm{P}$ into inorganic or organic $\mathrm{P}$ and other fractions can give an idea of shortand long-term $\mathrm{P}$ availability. Composts generally show a higher $\mathrm{P}$ availability about $60 \%$ of that supplied by inorganic $\mathrm{P}$ fertilizer in the year of application (Sinaj et al., 2002). The most easily desorbed and labile compounds are removed first with dilute reagents and the strength of the extractants increases stepwise to separate strongly bound $\mathrm{P}$ forms. Sequential chemical extraction 
methods have often been used to study the nature of $\mathrm{P}$ forms in soils (Adhami et al., 2013). Bioavailability of applied $\mathrm{P}$ in soils is directly dependent upon lability of $\mathrm{P}$ in the waste material (He et al., 2006; 2008). Phosphorus forms during composting are important to assess the agronomic value of manure compost and the risk associated with the land application. Most of the studies about $\mathrm{P}$ during composting only included total $\mathrm{P}$ content but information on only total $\mathrm{P}$ is insufficient to explain the nature or chemical forms of $\mathrm{P}$. The fractionation of $\mathrm{P}$ may provide knowledge of the availability, solubility and inter-conversion among P fractions (Shen et al., 2004). Little information is available on $\mathrm{P}$ fractions during composting of manure along with agro-waste. Our objective was to investigate the extractability and bioavailability of $\mathrm{P}$ in soils treated with poultry manure co-composted with sugarcane and cabbage wastes.

\section{Materials and Methods}

Poultry litter (PL) was collected from some of the many poultry farms around Abbottabad while sugarcane and cabbage wastes were collected from Fruit and Vegetable Market in the same area. The PL was co-composted with sugarcane waste (SW) and cabbage waste $(\mathrm{CW})$ in plastic bins $(>10 \mathrm{~L})$. Bins were arranged in rows under a tile-roofed shed. Sugarcane waste and $\mathrm{CW}$ were mixed at 0 , 25,33 and $50 \%$ with PL, respectively. Poultry litter without agro-waste was set as a control treatment. Waste material was co-composted up to 60 days. During composting, treatments were occasionally moistened and aerated equally. Moisture in the manure was maintained at $30 \%$ and samples were turned at weekly intervals. Additional water was added as required. After composting, manure samples were air dried, crushed, and sieved $(<0.5$ $\mathrm{mm})$ to ensure homogeneity. The physicochemical properties $(\mathrm{EC}, \mathrm{pH}$, total $\mathrm{N}$, total $\mathrm{C}, \mathrm{C}: \mathrm{N}$ etc) of the manure during co-composting were determined.

After composting, the manure samples were thoroughly mixed and $50 \mathrm{~g}$ sample was taken from each treatment. Total carbon content was determined by dry combustion using the method proposed in Nelson and Sommers, (1982). The pH of manure suspension was determined in water $(1: 5)$ using a pH meter (Model: HANNA HI 8520). The suspension was centrifuged and filtered through a Whatman \# 42 filter paper to determine the electrical conductivity (EC) using the EC meter (Model: 4320 JENWAY). Kjeldahl method was used to determine nitrogen $(\mathrm{N})$ according to APHA (1995). Carbon to $\mathrm{N}$ ratio was calculated based on the total carbon and total Kjeldahl $\mathrm{N}$ concentration (Zhu et al., 2004). Sample weighing $0.25 \mathrm{~g}$ was digested in a mixture (1:3) of per chloric acid $\left(\mathrm{HClO}_{4}\right)$ and nitric acid $\left(\mathrm{HNO}_{3}\right)$ for the determination of total concentrations of macro- and micro-elements potassium $(\mathrm{K})$, calcium $(\mathrm{Ca})$, magnesium $(\mathrm{Mg})$, sodium $(\mathrm{Na})$, copper $(\mathrm{Cu})$, iron $(\mathrm{Fe})$, manganese $(\mathrm{Mn})$ and zinc $(\mathrm{Zn})$, using an atomic absorption spectrophotometer (AAS). Total phosphorus in the digest was determined by phospho-molybdate blue method and absorbance was measured by a spectrophotometer at a wavelength of $710 \mathrm{~nm}$ (Olsen and Sommers, 1982). Chemical compositions of soil and composted manure are given in Table 1-2-3. 
Table 1. Chemical composition of soils used for the study

\begin{tabular}{llll}
\hline Parameters & Unit & Silt loam & Sandy clay \\
\hline Total C & $\mathrm{g} \mathrm{kg}^{-1}$ & 26.9 & 31.4 \\
Total $\mathrm{N}$ & $\mathrm{g} \mathrm{kg}^{-1}$ & 32.3 & 43.8 \\
Extr. $\mathrm{P}$ & $\mathrm{mg} \mathrm{kg}^{-1}$ & 59.3 & 75.8 \\
Extr.Ca & $\mathrm{mg} \mathrm{kg}^{-1}$ & 89.7 & 81.2 \\
Extr. $\mathrm{Mg}$ & $\mathrm{mg} \mathrm{kg}^{-1}$ & 75.6 & 51.7 \\
Extr. $\mathrm{K}$ & $\mathrm{mg} \mathrm{kg}^{-1}$ & 69.8 & 67.7 \\
Extr. $\mathrm{Cu}$ & $\mathrm{mg} \mathrm{kg}^{-1}$ & 8.3 & 12.7 \\
Extr. $\mathrm{Fe}$ & $\mathrm{mg} \mathrm{kg}^{-1}$ & 29.6 & 31.6 \\
Extr.Mn & $\mathrm{mg} \mathrm{kg}^{-1}$ & 31.5 & 35.5 \\
Extr. $\mathrm{Zn}$ & $\mathrm{mg} \mathrm{kg}^{-1}$ & 42.3 & 62.8 \\
EC $(1: 5)$ & $\mathrm{dS} \mathrm{m}^{-1}$ & 0.6 & 0.9 \\
pH $(1: 5)$ & & 7.6 & 7.1 \\
\hline
\end{tabular}

Table 2. Chemical composition of poultry litter (PL) co-composted with sugarcane waste (SW)

\begin{tabular}{|c|c|c|c|c|c|}
\hline \multirow[t]{2}{*}{ Parameter } & \multirow[t]{2}{*}{ Unit } & \multicolumn{4}{|c|}{ Percent application of SW in PL } \\
\hline & & 0 & 25 & 33 & 50 \\
\hline Total C & $\mathrm{g} \mathrm{kg}^{-1}$ & 350 & 360 & 380 & 420 \\
\hline Total N & $\mathrm{g} \mathrm{kg}^{-1}$ & 25 & 21 & 19 & 15 \\
\hline Total P & $\mathrm{g} \mathrm{kg}^{-1}$ & 21.8 & 19.6 & 17.2 & 15.5 \\
\hline Total Ca & $\mathrm{mg} \mathrm{kg}^{-1}$ & 1274 & 1319 & 1334 & 1356 \\
\hline Total Mg & $\mathrm{mg} \mathrm{kg}^{-1}$ & 437 & 450 & 457 & 464 \\
\hline Total K & $\mathrm{mg} \mathrm{kg}^{-1}$ & 800 & 811 & 822 & 829 \\
\hline Total $\mathrm{Cu}$ & $\mathrm{mg} \mathrm{kg}^{-1}$ & 106 & 86 & 71 & 27 \\
\hline Total Fe & $\mathrm{mg} \mathrm{kg}^{-1}$ & 247 & 235 & 206 & 190 \\
\hline Total Mn & $\mathrm{mg} \mathrm{kg}^{-1}$ & 182 & 173 & 152 & 139 \\
\hline Total Zn & $\mathrm{mg} \mathrm{kg}^{-1}$ & 105 & 91 & 86 & 60 \\
\hline EC (1:5) & $\mathrm{dS} \mathrm{m}^{-1}$ & 4.3 & 4.0 & 3.7 & 3.4 \\
\hline $\mathrm{pH}(1: 5)$ & & 8.9 & 8.5 & 8.3 & 8.1 \\
\hline
\end{tabular}


Table 3. Chemical composition of poultry litter (PL) co-composted with cabbage waste (CW)

\begin{tabular}{|c|c|c|c|c|c|}
\hline Parameter & Unit & Perce & cation & to PL & \\
\hline & & 0 & 25 & 33 & 50 \\
\hline Total C & $\mathrm{g} \mathrm{kg}^{-1}$ & 350 & 360 & 350 & 370 \\
\hline Total N & $\mathrm{g} \mathrm{kg}^{-1}$ & 25 & 18 & 15 & 11 \\
\hline Total P & $\mathrm{g} \mathrm{kg}^{-1}$ & 21 & 18 & 16 & 15 \\
\hline Total Ca & $\mathrm{mg} \mathrm{kg}^{-1}$ & 1274 & 1322 & 1339 & 1350 \\
\hline Total Mg & $\mathrm{mg} \mathrm{kg}^{-1}$ & 437 & 445 & 449 & 463 \\
\hline Total K & $\mathrm{mg} \mathrm{kg}^{-1}$ & 800 & 809 & 815 & 825 \\
\hline Total $\mathrm{Cu}$ & $\mathrm{mg} \mathrm{kg}^{-1}$ & 106 & 89 & 76 & 29 \\
\hline Total Fe & $\mathrm{mg} \mathrm{kg}^{-1}$ & 247 & 214 & 195 & 182 \\
\hline Total Mn & $\mathrm{mg} \mathrm{kg}^{-1}$ & 182 & 167 & 142 & 120 \\
\hline Total Zn & $\mathrm{mg} \mathrm{kg}^{-1}$ & 105 & 85 & 69 & 55 \\
\hline EC (1:5) & $\mathrm{dS} \mathrm{m}^{-1}$ & 4.3 & 3.9 & 3.5 & 3.3 \\
\hline $\mathrm{pH}(1: 5)$ & & 8.9 & 8.3 & 8.1 & 7.9 \\
\hline
\end{tabular}

\subsection{Pot experiment}

Two types of soil (sandy clay and silt loam) were sampled to a depth of $20 \mathrm{~cm}$ from different locations across Abbottabad, air-dried for 2 days and screened through a $2 \mathrm{~mm}$ sieve. The physicochemical properties of the soils were determined and given in Table 1.A pot experiment was conducted using plastic bins each of which was filled with $5 \mathrm{~kg}$ soil. The final co-composted manure was applied to the two soils to determine the extractability and bioavailability of $\mathrm{P}$ from the soils. The compost was sampled, air dried, sieved and then characterized for $\mathrm{pH}$, EC, texture, organic matter and extractable nutrients $(\mathrm{N}, \mathrm{P}, \mathrm{K}, \mathrm{Ca}, \mathrm{Mg}$ etc). Co-composted PL was applied at two levels based on 200 and $400 \mathrm{~kg}$ total $\mathrm{P} \mathrm{ha}^{-1}$. Soil treated with sole PL without crop waste (1:0) was set as control treatment. The experiment was a $(2 \times 2 \times$ $4 \times 2$ ) factorial combination of two agro-wastes (sugarcane waste and cabbage waste) $\mathrm{x}$ two soil types $\mathrm{x}$ four mixing ratios $\mathrm{x}$ two application rates based on $\mathrm{P}$ content, resulting in 32 experimental units arranged into a completely randomized design. There were three replications for each experimental unit. Irrigation was done at twice the daily pan evaporation. Maize plants were grown for 8 weeks and then harvested for shoot biomass determination. Harvested shoots were rinsed thoroughly with distilled water and oven dried for $48 \mathrm{~h}$ at $60^{\circ}$ C. After weighing the resulting dry mass, samples were milled and digested in a mixture $(3: 1)$ of nitric $\left(\mathrm{HNO}_{3}\right)$ and perchloric $\left(\mathrm{HClO}_{4}\right)$ acids to determine the phosphorus $(\mathrm{P})$ concentration. Colour development followed the phosphomolybdate blue method and $\mathrm{P}$ concentration was determined using spectrophotometrically at a wavelength of $710 \mathrm{~nm}$ (Olsen and Sommers 1982). Phosphorus recovery was calculated as equation 1 : 
P recovery $=\frac{100(\mathrm{P} \text { uptake in the fertilized pot })}{P \text { applied per pot }}$

Total $\mathrm{P}$ in the post-harvest soil samples was determined by acids digestion; the $\mathrm{P}$ fractions were also determined. Phosphorus fractionation was done using the modified sequential extraction procedure of Hedley et al. (1982) as described in Eneji et al. (2003). Soil samples were fractionated into readily plant-available $\mathrm{P}$, labile inorganic $\mathrm{P}$ (another plant-available fraction), sesquioxide(Fe-oxide and Al-oxide) associated inorganic $\mathrm{P}$ and $\mathrm{Ca}$-associated $\mathrm{P}$ by sequential extraction with de-ionized water, $0.5 \mathrm{M} \mathrm{NaHCO}$ ( $\mathrm{pH} 8.5$ ), $0.1 \mathrm{M}$ $\mathrm{NaOH}$, and $1 M \mathrm{HCl}$, respectively. In the $\mathrm{P}$ extraction procedure, $0.5 \mathrm{~g}$ soil sample was placed in $50 \mathrm{~mL}$ centrifuge tube and was sequentially extracted with $30 \mathrm{~mL}$ each of de-ionized water, $0.5 \mathrm{MNaHCO} 3,0.1 \mathrm{MNaOH}$, and $1 \mathrm{MHCl}$. The extraction with each reagent was carried out in triplicate after $16 \mathrm{~h}$ of end-to-end shaking at room temperature and centrifuged at $10000 \mathrm{rpm}$ for 15 min. Supernatants were filtered and the $\mathrm{P}$ contents determined calorimetrically (Olsen and Sommers, 1982). The EC and pH of compost amended soil samples were measured in soil-water- suspensions (1:5), using $\mathrm{pH}$ and $\mathrm{EC}$ meters.

\subsection{Statistical analysis}

The data were subjected to analyses of variance (ANOVA) using Stat-view software. The least significant difference (LSD) at $\mathrm{P} \leq 0.05$ was used to compare treatment means. Phosphorus forms in the soil were correlated with the P uptake and maize biomass using regression analysis.

\section{Results}

\subsection{Maize biomass}

Maize biomass yield was varied with the crop waste added to the poultry manure (Figure 1). The ratio of crop waste in the poultry manure was positively associated with the amount of biomass irrespective of the soil type. Maize biomass increased significantly as the compost application rates increased and decreased as the ratio of sugarcane and cabbage wastes in the compost increased. Soils receiving sole manure treatment without agro-waste gave a lower biomass than other manure amendments and the biomass yield was higher in the sandy clay soil than silt loam soil. Dry biomass of 135 and $122 \mathrm{~g}$ was obtained from sandy clay soil amended with PL $+50 \% \mathrm{SW}$ and $\mathrm{CW}$, respectively at application rate of 400 $\mathrm{kg} \mathrm{P} \mathrm{ha}{ }^{-1}$. Plant biomass was less in the compost containing $\mathrm{CW}$ than that containing $\mathrm{SW}$ and was higher in sandy clay than silt loam soil. For the sandy-clay soil, the biomass yields were107, 115 and $124 \mathrm{~g}$ after amendment with composted PL+ 25,33 and $50 \% \mathrm{SW}$ at $200 \mathrm{~kg} \mathrm{P} \mathrm{ha}^{-1}$ and 117,127 and $135 \mathrm{~g}$, respectively at the manure application rate of $400 \mathrm{~kg} \mathrm{P} \mathrm{ha}^{-1}$. Maize growth increased as the compost application rate increased (Table 4). 

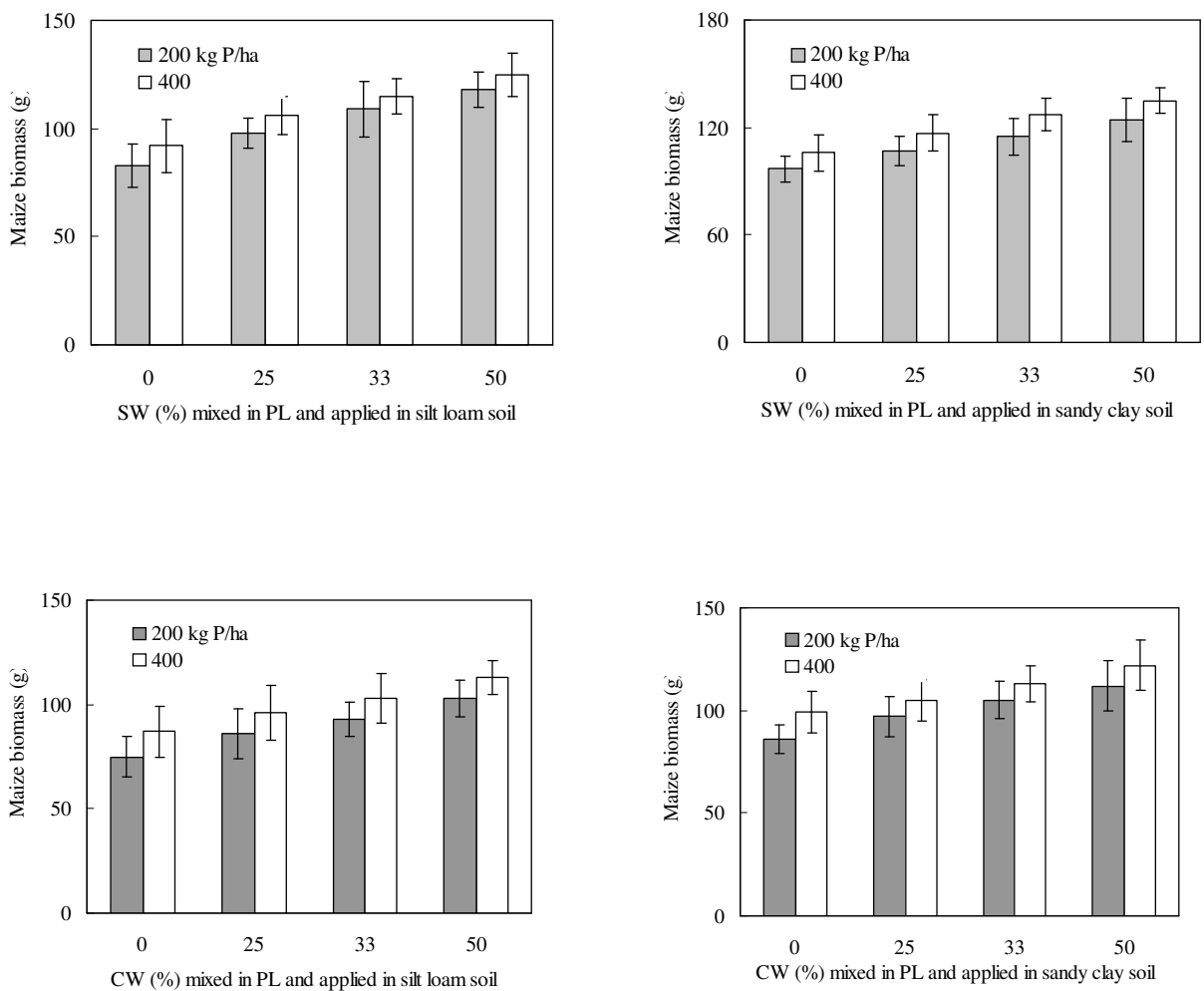

Figure 1. Maize dry biomass as affected by composted manure containing sugarcane (SW) and cabbage (CW) wastes applied at 200 and $400 \mathrm{~kg} \mathrm{Pha}^{-1}$ 
Table 4. Phosphorus concentration in maize shoot as affected by the application of poultry manure composted with sugarcane and cabbage wastes.

\begin{tabular}{|c|c|c|c|c|}
\hline \multirow[t]{3}{*}{ Agro-waste } & \multirow[t]{3}{*}{ Soil } & \multirow{3}{*}{$\begin{array}{l}\text { Application } \\
(\%) \\
\end{array}$} & \multicolumn{2}{|c|}{$\begin{array}{l}\text { Shoot } \mathrm{P} \text { concentration } \\
\left(\mathrm{mg} \mathrm{kg}^{-1}\right)\end{array}$} \\
\hline & & & \multicolumn{2}{|c|}{ Compost application rate $\left(\mathrm{kg} \mathrm{P} \mathrm{ha}^{-1}\right)$} \\
\hline & & & 200 & 400 \\
\hline \multirow{8}{*}{$\begin{array}{l}\text { Sugarcane } \\
\text { waste }\end{array}$} & Silt loam & 0 & 97.1 & 107.9 \\
\hline & & 25 & 101.4 & 111.3 \\
\hline & & 33 & 108.7 & 115.0 \\
\hline & & 50 & 114.3 & 118.4 \\
\hline & Sandy clay & 0 & 120.6 & 118.2 \\
\hline & & 25 & 126.3 & 129.5 \\
\hline & & 33 & 131.3 & 137.7 \\
\hline & & 50 & 138.3 & 142.3 \\
\hline \multirow{9}{*}{$\begin{array}{l}\text { Cabbage } \\
\text { waste }\end{array}$} & Silt loam & 0 & 85.1 & 91.2 \\
\hline & & 25 & 91.7 & 96.9 \\
\hline & & 33 & 96.9 & 103.5 \\
\hline & & 50 & 103.5 & 107.7 \\
\hline & Sandy clay & 0 & 96.4 & 104.3 \\
\hline & & 25 & 102.2 & 108.1 \\
\hline & & 33 & 107.4 & 112.6 \\
\hline & & 50 & 112.3 & 117.3 \\
\hline & LSD & $.05)$ & 7.3 & 7.8 \\
\hline
\end{tabular}




\subsection{Phosphorus concentration in maize}

The $\mathrm{P}$ concentration in maize shoot was lower in soils amended with compost containing CW than the compost containing SW (Table 4). However, the concentration increased with increasing rates of application and decreased as the amount of sugarcane and cabbage wastes in the compost increased. Shoot $\mathrm{P}$ concentrations differed by ratio of agro-waste in manure as $0<25<33<50 \%$. The sandy clay soil gave higher concentration of $\mathrm{P}$ in plant shoot than the silt loam soil. Phosphorus concentrations in the shoot of maize treated with sole manure compost at $200 \mathrm{~kg} \mathrm{P}^{-1}$ were 97.1 and $85.1 \mathrm{mg} \mathrm{kg}^{-1}$ in silt loam soil followed by 120.6 and $96.4 \mathrm{mg} \mathrm{kg}^{-1}$ in sandy clay soil (Table 4). Phosphorus concentration increased by $8.5,13.8$ and $20.3 \%$ after application of PL with 25, 33 and 50\% SW and by $6.5,11.4$ and $17.6 \%$ after application of PL with 25, 33 and 50\% CW in sandy clay soil at the manure application rate of $400 \mathrm{~kg} \mathrm{P} \mathrm{ha}^{-1}$. Phosphorus recovery was also calculated among the manure treatments (Figure 2). This $\mathrm{P}$ variation in plants could be related to the amount of extractable $\mathrm{P}$ in the manure amendments.
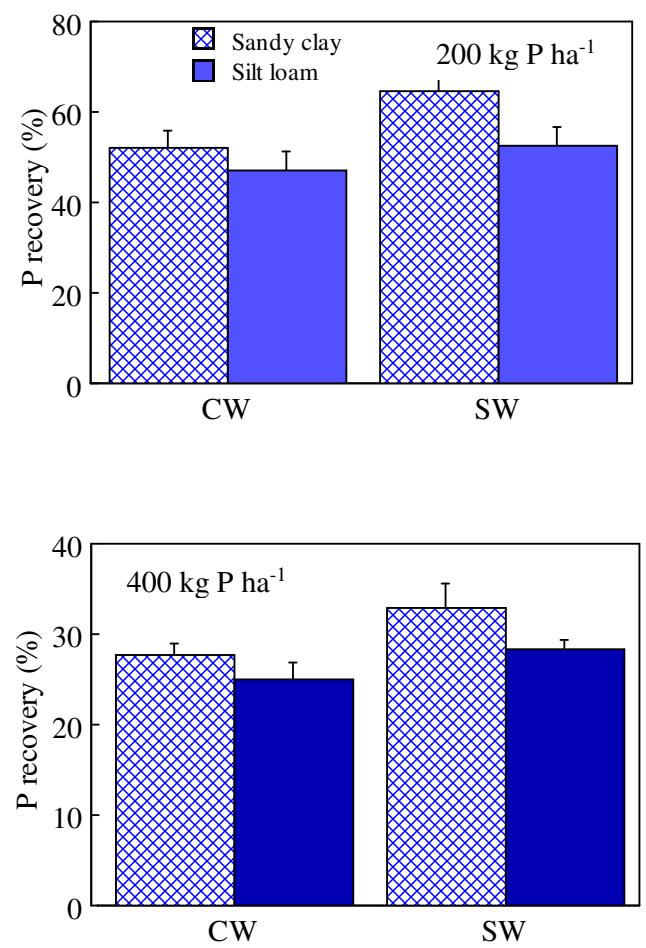

Agro-waste

Figure 2. Phosphorus recovery $\left(\mathrm{mg} \mathrm{kg}^{-1}\right)$ from soil amended with poultry litter co-composted with sugarcane (SW) and cabbage (CW) wastes at 200 and $400 \mathrm{~kg} \mathrm{P} \mathrm{ha}^{-1}$. 


\subsection{Phosphorus fractions in post-harvest soil}

Phosphorus fractions in post-harvest soil varied with manure amendments (Figure 3) and were lower in soils amended with compost containing $\mathrm{CW}$ than that containing SW. Across soils, the fractions differed in the order $\mathrm{HCl}-\mathrm{P}(\mathrm{Ca}+\mathrm{Mg}$-bound $)>\mathrm{H}_{2} \mathrm{O}-\mathrm{P}$ (water soluble $\mathrm{P}$ ) $>\mathrm{NaHCO}_{3}-\mathrm{P}$ (readily plant-available $\mathrm{P}$ ) $>\mathrm{NaOH}-\mathrm{P}$ ( $\mathrm{Fe}+\mathrm{Al}$-bound). Organic $\mathrm{P}$ concentration was higher in PL+ SW treated soils. The sandy clay soil contained more $\mathrm{P}$ than the silt loam soil. The vari- ations in $\mathrm{P}$ from soils could be related to the $\mathrm{P}$ level of the manure compost supplemented with agro-waste. This study showed that $\mathrm{P}$ fractions have been moderated by the application of co-compost, indicating its benefit for sustainable soil fertility management. Regression equations, determinant $\left(\mathrm{R}^{2}\right)$ and correlation coefficient ( $r$ ) explaining the relationship between shoot $\mathrm{P}$ and $\mathrm{P}$ fractions in soils were calculated (Figure 4). The concentrations of $P$ in maize shoot showed significant positive relationship with extractable $\mathrm{P}$ fractions in soil, especially the $\mathrm{H}_{2} \mathrm{O}-\mathrm{P}$.
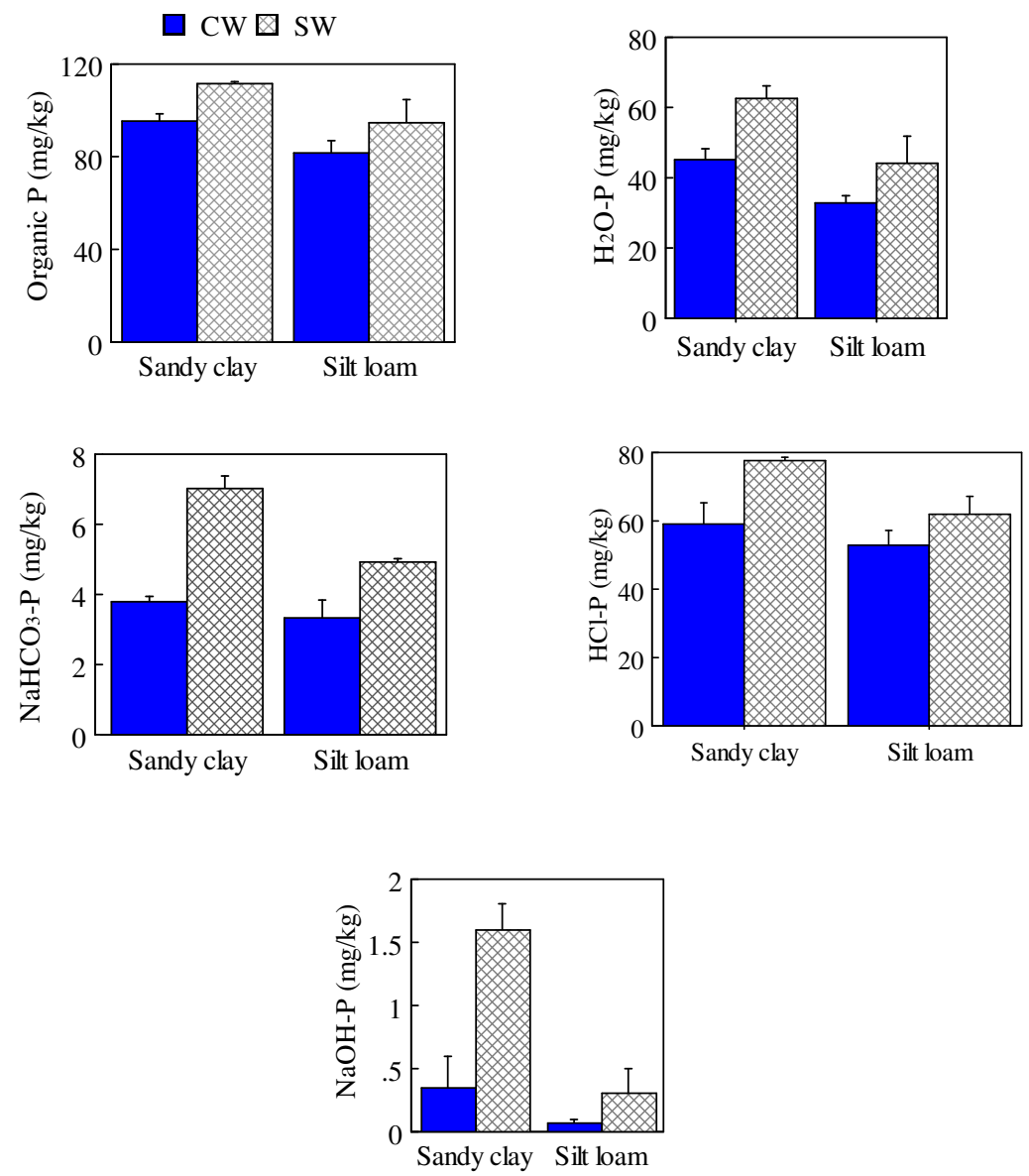

Figure 3. Phosphorus fractions $\left(\mathrm{mg} \mathrm{kg}^{-1}\right)$ in post-harvest soils amended with poultry manure co-composted with sugarcane $(\mathrm{SW})$ and cabbage $(\mathrm{CW})$ wastes 

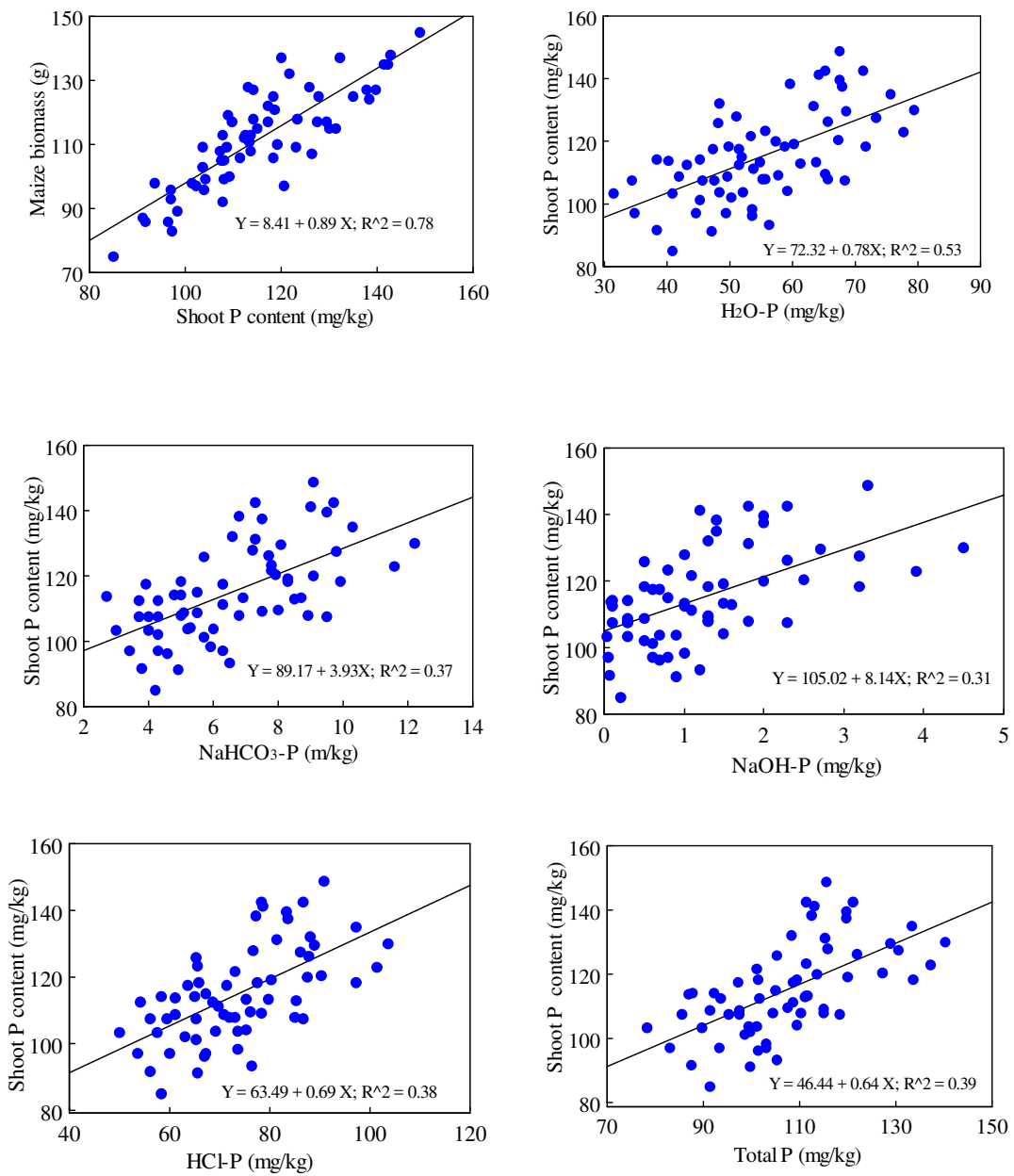

Figure 4. Regression plot of maize shoot $P$ concentrations versus $P$ fractions in soils amended with compost.

\section{Discussion}

The co-composted PL increased maize growth relative to $\mathrm{PL}$ alone with the best biomass occurring at the treatment rate of $400 \mathrm{~kg} \mathrm{P} \mathrm{ha}{ }^{-1}$. Maize biomass increased significantly as the compost application rates increased. Maize biomass and available $\mathrm{P}$ in soil varied in the order PL co-composted with sugarcane waste and cabbage waste (\%) $50>33>25>0$. Plant biomass was less in the compost of $\mathrm{CW}$ as compared to co-compost containing SW. Biomass was higher in sandy clay than silt loam soil. Maize growth enhance with the higher application of manure compost. This study showed that composted manure with agrowastes could be a viable resource of plant nutrient. Improvements in the plant growth in soils applied with manure were indicative of the enhanced nutrient availability following transformation from organic to 
inorganic forms. Edwards et al. (2007) reported greater yield of maize after compost application as compared to the commercial fertilizer. Irshad et al. (2002) reported higher biomass yield and high nutrient concentrations in soil treated with composted manure. The significance of compost in enhancing soil fertility for plant growth has been amply reported (Gul et al., 2016; Amanullah et al., 2015; Dada et al., 2014; Zai et al., 2008). D'Hose et al. (2012) found that compost amendment considerably increased dry matter yields of different crops. The application of composted feedlot manure increased maize yield similar to commercial fertilizers (Ahsok et al., 2005). The increase in the yield and yield components of a crop with the compost application may be attributed to the availability of nutrients. Comparatively, the co-compost showed better plant growth, possibly because of the complimentary effects of the crop wastes. Increased microbial activity, biochemical transformations and mineralization of recalcitrant $\mathrm{P}$ fraction have been associated with the addition of organic manures (Nziguheba et al., 1998).

The $\mathrm{P}$ concentration in maize shoot was higher in soils amended with compost containing SW than the compost containing $\mathrm{CW}$. Phosphorus contents in maize shoot were higher in sandy clay than silt loam soil. Phosphorus recovery was higher in soil treated with PL co-composted sugarcane waste (Figure 2). Ratio of agro-waste in manure significantly elevated $\mathrm{P}$ concentration in maize. Phopshorus variation in plants could be related to the amount of extractable $\mathrm{P}$ in the manure amendments. The variation in $\mathrm{P}$ concentration in maize after manure amendments could be related to the altered mineral composition of soils. Irshad et al. (2002) reported that increased application of composted manure profoundly increased the uptake of plant nutrients. Soil amendment with poultry litter showed enhanced the elemental concentrations in crops. Singh and Amberger (1991) attributed increased $\mathrm{P}$ availability to plants to the solubilization of
P by organic acids present in the compost. According to Singh et al. (2004), compost application increased microbial activities and availability of mineral nutrients for crop plants. Amendment of soil with compost increased soil P (Eichler-Löbermann et al., 2007). Application of co-composted material significantly $(P<0.05)$ reduced the available $\mathrm{P}$ in soils relative to the poultry litter without agro-waste. An increased plant $\mathrm{P}$ uptake in compost-amended soils has been reported (Sinaj et al., 2002). In contrast, Sikora and Enkiri (2005) found little effect of manure composting on $\mathrm{P}$ availability. More $\mathrm{P}$ was recovered from the sandy clay than the silt loam soil. Also, more P was recovered from the sugarcane waste than cabbage waste. The higher application of total $\mathrm{P}$ in the form of composted manure reduced the $\mathrm{P}$ recovery in maize. Co-composted PL increased the extractable P fractions in the soils. The $\mathrm{P}$ fractions in the post-harvest soils varied in the order $\mathrm{HCl}-\mathrm{P}>\mathrm{H}_{2} \mathrm{O}-\mathrm{P}>\mathrm{NaHCO}_{3}-\mathrm{P}$ $>\mathrm{NaOH}-\mathrm{P}$. Irrespective of the fraction, $\mathrm{P}$ was significantly higher in the sandy clay than the silt loam soil. Poultry litter co-composted with sugarcane waste has higher levels of $\mathrm{P}$ fractions in soils. The variations in P from soils could be related to the P level of the manure compost supplemented with agro-waste. Generally, the fractional abundance of $\mathrm{P}$ was moderated by the application of co-compost, indicating its benefit for sustainable soil fertility management. Hirata et al. (1999) reported an increase in the inorganic $\mathrm{P}$ concentrations in the soil after continuous application of manures or composts. Alamgir and Marschner (2016) reported that the concentrations of various $P$ pools were strongly affected by soil properties such as $\mathrm{pH}$ and organic matter content and further modulated by the properties of the plant residues. It has also been reported elsewhere that size and forms of $\mathrm{P}$ in soil depends on the soil properties such as $\mathrm{pH}$, organic matter content, soil texture and clay mineralogy (Chatterjee et al., 2014). Gagnon and Simard 
(2003) obtained higher soil labile $\mathrm{P}$ with the addition of composted poultry litter, vegetable residues and sheep manure than with composts of beef and dairy cattle manure. Sharpley and Moyer (2000) observed differences in the amount and relative distribution of $\mathrm{P}$ forms in manure due to the composting process and material added. Irshad et al. (2013) reported considerably varied extractability of elements with the type of composted manure.

\section{Conclusions}

The co-compost of PL plus 50\% agro-waste showed best improved maize growth and increased availability of $\mathrm{P}$ as compared to PL alone in soils. Phosphorus concentration in the soils was a function of rate of application of composted manure and crop waste additive. The $\mathrm{P}$ fractions varied in the order $\mathrm{HCl}>\mathrm{H}_{2} \mathrm{O}>$ $\mathrm{NaHCO}_{3}>\mathrm{NaOH}$ but availability was higher at the application rate of 400 than $200 \mathrm{~kg} \mathrm{P} \mathrm{ha}^{-1}$. Phosphorus fractions were more abundant in the sandy clay than the silt loam soil. Regression analysis showed that $\mathrm{P}$ concentrations in maize shoot were directly related to the extractable $\mathrm{P}$ fractions of soil. The application of PL co-composted with sugarcane and cabbage wastes would be beneficial to maize growth and moderating soil $P$ availability.

\section{References}

Adhami, E., Owliaie, H.R., Molavi, R., Rezaei Rashti, M., Esfandbod, M. 2013. Effects of soil properties on phosphorus fractions in subtropical soils of Iran. J. Soil Sci. Plant Nutr. 13, 11-21.

Ahsok, K., Gautam, R.C., Singh, R., Rana, K.S. 2005. Growth, yield and economics of maize wheat cropping sequences as influenced by integrated nutrient management. Ind. J. Agric. Sci.75, 706-711.
Alamgir, M., Marschner, P. 2016. Changes in P pools over three months in two soils amended with legume residues. J. Soil Sci. Plant Nutr. 16, 76-87.

Amanullah, K.I., Jan, A., Jan, M.T., Khalil, S.K., Shah, Z. 2015. Compost and nitrogen management influence productivity of spring maize (Zea mays L.) under deep and conventional tillage systems in semi-arid regions. Commun. Soil Sci. Plant Anal. 46, 1566-1578.

D’Hose, T., Cougnon, M., De Vliegher, A., Willekens, K., Van Bockstaele, E., Rehe, D. 2012. Farm compost application: effects on crop performance. Compost Sci. Util. 20, 49-56.

Dada, O.A., Togun, A.O., Asediran, J.A., Nwilene, F.E. 2014. Growth, nutrient uptake and yield of upland rice as influenced by two composts types in tropical rainforest derived Savannah transition zone. Agric. Sc. 5, 383-393.

Chatterjee, D., Datta, S.C., Manjaiah, K.M. 2014. Fractions, uptake and fixation capacity of phosphorus and potassium in three contrasting soil orders. J. Soil Sci. Plant Nutr. 14, 640-656.

Edwards, S., Arefayne, A., Hailu, A., Tewoldeberhan, G. 2007. Impact of compost use on crop yields in Tigray, Ethiopia. Natural Resource Management and Environment Department. Food and Agriculture Organization of the United Nations (FAO), Rome.

Eichler-Löbermann, B., Köhne, S., Köppen, D. 2007. Effect of organic, inorganic, and combined organic and inorganic $\mathrm{P}$ fertilization on plant $\mathrm{P}$ uptake and soil P pools. J. Plant Nutr. Soil Sci. 170, 623-628.

Eneji, A.E., Honna, T., Yamamoto, S., Masuda, T., Irshad, M. 2003. Changes in humic substances and phosphorus fractions during composting. Commun. Soil Sci. Plant Anal. 34, 2303-2314. 
Fan, J.L., Ziadi, N., Gagnon, B., Hu, Z.Y. 2010. Soil phosphorus fractions following annual paper mill biosolids and liming materials application. Canad. J. Soil Sci. 90, 467-479.

Fialho, L., Silva, W., Milori, D., Simões, M., Martin, L. 2010. Characterization of organic matter from composting of different residues by physicochemical and spectroscopic methods. Bioresour. Technol. 101, 1927-1934.

Gagnon, B.,Simard, R.R. 2003. Soil P fractions as affected by on-farm composts in a controlled incubation study. Canad. J. Soil Sci. 83, 223-226.

Gul, S., Naz, A., Khan, A., Nisa, S., Irshad, M. 2016. Phytoavailability and leachability of heavy metals from contaminated soil treated with composted livestock manure. Soil Sed. Contam. An Inter. J. 25, 181-194.

He, Z., Griffin, T.S. and Honeycutt, C.W. 2006. Soil phosphorus dynamics in response to dairy manure and inorganic fertilizer applications. Soil Sci. 171, 598-609.

He, Z., Honeycutt, C.W., Cade-Menun, B.J., Senwo, Z.N., Tazisong, I.A. 2008. Phosphorus in poultry litter and soil: Enzymatic and nuclear magnetic resonance characterization. Soil Sci. Soc. Am. J. $72,1425-1433$.

He, Z., Griffin, T.S., Honeycutt, C.W. 2006. Soil phosphorus dynamics in response to dairy manure and fertilizer applications. Soil Sci. 171, 598-609.

Hedley, M.J., Stewart, J.W., Chauhan, B.S. 1982. Changes in inorganic and organic soil phosphorus fractions induced by cultivation practices and by laboratory incubation. Soil Sci. Soc. Am. J. 46, 970-976.

Hirata, H., Watanabe, K., Fukushima, K., Aoki, M., Imamura, R., Takahashi, M. 1999. Effect of continuous application of farmyard manure and inorganic fertilizer for 9 years on changes in phosphorus compounds in plow layer of an upland Andosol. Soil Sci. Plant Nutr. 45, 577-590.
Irshad, M., Yamamoto, S., Eneji, A.E., Honna, T., Endo, T. 2002. Influence of composted manure and salinity on growth and nutrient content of maize tissue. Sand Dune Res. 49, 1-10.

Irshad, M., Eneji, A.E., Hussain, Z., Ashraf, M. 2013. Chemical characterization of fresh and composted livestock manures. J. Soil Sci. Plant Nutr. 13, 115-121.

Johnston, A. 2001. Phosphorus Fertilization- Sources and efficiency. A regional newsletter. Potash and Phosphate Institute (PPI) of Canad. pp. 2-3.

Mehta, C.M., Uma, P., Franke-Whittle, I.H., Sharma, A.K. 2014. Compost: its role, mechanism and impact on reducing soil-borne plant diseases. Waste Manage. 34, 607-622.

Nelson, D.W., Sommers, L.E. 1982. Organic carbon. In: Methods of Soil Analysis, Part 2, ASA, SSSA, Madison, WI, USA, pp. 561-579.

Nziguheba, G., Palm, C.A., Buresh, R.J., Smith-son, P.C. 1998. Soil phosphorus fractions and adsorption as affected by organic and inorganic sources. Plant Soil. 198, 159-168.

Paradelo, R., Barral, M.T. 2012. Evaluation of the potential capacity as biosorbents of two MSW composts with different $\mathrm{Cu}, \mathrm{Pb}$ and $\mathrm{Zn}$ concentrations. Bioresour. Technol. 104, 810-813.

Romanya, J., Rovira, P. 2009. Organic and inorganic P reserves in rain-fed and irrigated calcareous soils under long-term organic and conventional agriculture. Geoderma. 15, 378-386

Sharpley, A., Moyer, B. 2000. Phosphorus forms in manure and compost and their release during simulated rainfall. J. Environ. Qual. 29, 1462-1469.

Shen, J., Li, R., Zhanga, F., Fan, J., Tang, C., Rengel, Z. 2004. Crop yields, soil fertility and phosphorus fractions in response to long-term fertilization under the rice monoculture system on a calcareous soil. Field Crops Res. 86, 225-238. 
Sikora, L.J., Enkiri, N.K. 2005. Comparison of phosphorus uptake from poultry litter compost with triple superphosphate in Codorus soil. Agron. J. 97, 668-673.

Sinaj, S., Traore, O., Frossard, E. 2002. Effect of compost and soil properties on the availability of compost phosphate for white clover (Trifolium repens L.). Nutr. Cycl. Agroecosyst. 62, 89-102.

Singh, C.P., Amberger, A. 1991. Solubilization and availability of phosphorus during decomposition of rock phosphate enriched straw and urine. Biol. Agric. Hortic. 7, 261-269.

Singh, V., Paudia, R.S., Totawat, K.L. 2004. Effect of phosphorus and zinc nutrition of wheat (Triticum aestivum L.) in soils of sub-humid southern plains of Rajasthan. Ind. J. Agron. 49, 46-48.
Snyder, C.S. 2002. Effects of Soil Flooding and Drying on Phosphorus Reactions. A regional newsletter. Potash and Phosphate Institute of Canada (PPIC). pp. 1-2.

Zai, A.K.E., Takatsugu, H., Tsutomu, M. 2008. Effects of compost and green manure of pea and their combinations with chicken manure and rapeseed residue on soil fertility and nutrient uptake in wheat-rice cropping system. Afr. J. Agric. 3, 633-639.

Zhang, T.Q., MacKenzie, A.F., Liang, B.C. 1995. Long-term changes in Mehlich-3 extractable P and $\mathrm{K}$ in a sandy clay loam soi1 under continuous corn. Canad. J. Soil Sci. 75, 361-367.

Zhu, N., Deng, C., Xiong, Y., Qian, H. 2004. Performance characteristics of three aeration systems in the swine manure composting. Bioresour. Technol. 95, 319-326. 